PRODUCTION

ENGINEERING ARCHIVES
2014, Vol. 4, No 3, pp 2-6

ISSN 2353-5156

ISSN 2353-7779 (print version)

(online version)

Article history: Received: 19.05.2014 Accepted: 26.05.2014 Online: 01.10.2014

\title{
Fatigue strength improvement of the AISI 316Ti austenitic stainless steel by shot peening
}

\author{
František Nový ${ }^{1}$, Sylvia Dundeková ${ }^{1}$, Otakar Bokůvka $^{1}$, Libor Trško $^{1}$ \\ ${ }^{1}$ Department of Materials Engineering, Faculty of Mechanical Engineering, University of Žilina, Univerzitná 8215/1, \\ 01026 Žilina, Slovak republic
}

\begin{abstract}
Stainless steels are structural materials used for a wide range of applications. One of the fields of application of these highly corrosion resistant materials is for various medical applications. Different methods of mechanical property improvement have been studied in recent years to increase the durability of components manufactured from these materials.

The main goal of this study was an analysis of fatigue strength improvement of the AISI 316Ti austenitic stainless steel by shot peening. A significant improvement of surface hardness, yield strength and fatigue limit by shot peening was observed in this study. This is despite increasing the surface roughness which usually degrades material's fatigue strength.
\end{abstract}

Key words - stainless steel, AISI 316L, shot peening, fatigue strength

\section{Introduction}

Stainless steels are often used in engineering material due to their advantageous properties such as high strength, good corrosion resistance and oxidation resistance at temperatures up to $550{ }^{\circ} \mathrm{C}$. They can be divided into four groups: Ferritic stainless steels are used mainly for electrical applications, Martensitic stainless steels in applications requiring high strength, Austenitic stainless steels for applications requiring good corrosion resistance, weldability and good forging properties. The last group is so called "Duplex" stainless steels which are able to combine the superior properties of the previously described groups by com- bination of various microstructures (WOLLMANN M., Mhaede M., Wagner L.; MuRTY Y. V. 2004).

Stainless steels are also very often used for medical devices, body implants and controlled drug delivery systems production. The most widely used stainless steel in medicine is type 316 with a microstructure consisting of austenite, which means the chemical composition of these grades must be optimized to maintain austenitic phase stability at room temperature as well as shifting of the Martensitic transformation temperature well below room temperature, as a result of the $\mathrm{Ni}$ addition. Usage of the AISI 316Ti is $\mathrm{Cr}-\mathrm{Ni}$ - Mo Austenitic stainless steel for medical equipment includes material decontamination and sterilization. 
During these processes strong chemical detergents and hot steam or high temperature heating are adopted (MURTY Y. V. 2004).

Corrosion resistance of stainless steels is result of the Passivation effect of $\mathrm{Cr}$ addition. Pitting and crevice corrosion resistance and microstructure control are given by the Mo and $\mathrm{N}$ addition. Addition of Ti is used for steel stabilization, thus minimizing carbide formation. Even when the corrosion resistance against pitting corrosion is well the AISI 316Ti steel is not resistant to the local corrosion in heavy corrosive operating conditions (containing mainly $\mathrm{Cl}-, \mathrm{Br}-, \mathrm{ClO}-$ ions; combination of high temperature, mechanical loading and corrosive environment) (ZATKALÍKOVÁ V., Bukovina M., ŠKorík V., Petreková L. 2010; FAJNOR P., LIPTÁKOVÁ T., ZATKALÍKOVÁ V., BREZINOVÁ J. 2011; SZKLARSKA - SMIALOWSKA, Z. 2005; HADZIMA, B.; LIPTÁKOVÁ, T. 2008; LIPTÁKOVÁ, T. 2009).

It is well known that mechanical treatments can be successfully used to increase the fatigue limit, especially in the case of notched parts. One of the most widely used surface treatment, which can be applied to structural components with general shape and dimensions, is shot peening. Besides its flexibility, other advantages are the relative low cost of the shot peening treatment and low environmental impact with respect to other treatments used with the same aim. The positive effect of shot peening on the fatigue properties is generally related to its ability to introduce a compressive residual stress state to the surface layer of material and to the surface work hardening created by the not uniform plastic deformation. (PARIENTE, I.F., Guagliano M. 2009; YU-Kui G. 2004; ZHANG P., LINDEMANN J., LEYENS L. 2010; LUONG H, HILL M.R. 2010; Miková K., Guagliano M., BokŮVka O., TRŠKO L., NOVÝ F. 2012).

\section{Experimental material}

Experimental examination was performed on $\mathrm{Cr}-\mathrm{Ni}-\mathrm{Mo}$ Austenitic stainless steel (commercially referred to AISI 316Ti, STN 41 7348), stabilized by titanium. This steel is non-magnetic with very good resistance to acids. Results of quantitative chemical analysis of AISI 316Ti steel are given in Tab. 1 The microstructure of this steel (Fig. 1) is formed by austenitic grains with a great number of deformation twins.

Table 1. Results of quantitative chemical analysis of AISI 316 Ti steel (in weight \%)

\begin{tabular}{|c|c|c|c|c|}
\hline $\mathrm{Cr}$ & $\mathrm{Ni}$ & $\mathrm{Mo}$ & $\mathrm{Mn}$ & $\mathrm{Ti}$ \\
\hline 17.55 & 12.96 & 2.54 & 1.63 & 0.37 \\
\hline $\mathrm{C}$ & $\mathrm{Si}$ & $\mathrm{P}$ & $\mathrm{S}$ & $\mathrm{Fe}$ \\
\hline 0.058 & 0.81 & 0.033 & 0.037 & rest \\
\hline
\end{tabular}

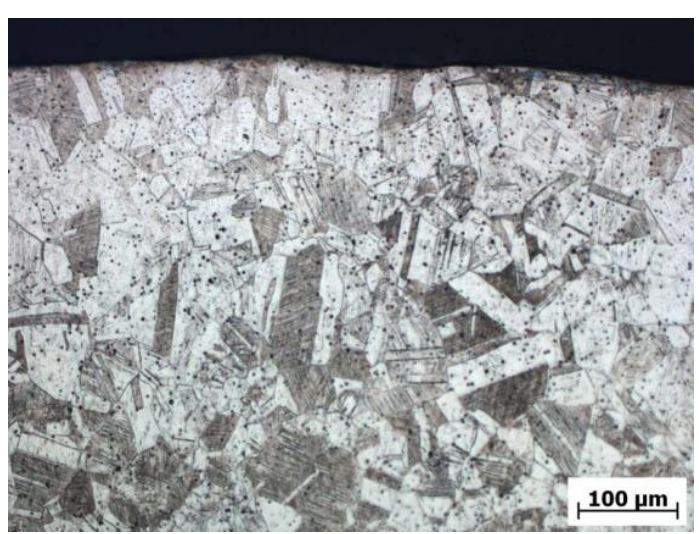

Fig. 1. Microstructure of AISI 316Ti steel, electrolytic etching.

Source: own study.

From a rod of $14 \mathrm{~mm}$ in diameter round specimens were machined for tensile and fatigue tests, both with gauge length diameter of $8 \mathrm{~mm}$. Specimens for tensile tests (3 pcs) and specimens for fatigue tests (19 pcs) were ground and the resulting surface roughness of test specimens was: arithmetical mean roughness $\mathrm{Ra}=1.1 \mu \mathrm{m}$ and roughness height $\mathrm{Rz}=7.35 \mu \mathrm{m}$. Part of fatigue test specimens ( $7 \mathrm{pcs}$ ) were shot peened with quenched steel shots with hardness of $40 \div 50 \mathrm{HRC}$, Almen intensity was $8 \mathrm{~A}$ with $100 \%$ coverage. The roughness in the gauge length of the specimens after shot peening was $\mathrm{Ra}=1.75 \mu \mathrm{m}$ and $\mathrm{Rz}=9.40 \mu \mathrm{m}$.

\section{Experimental results}

\subsection{Surface hardening}

Microhardness analysis of the surface after shot peening was performed on the metallographic cross section of treated material from the surface to the middle of the specimen. During the analysis 10 measurements were carried out and distances be- 
tween the individual indentations were $75 \mu \mathrm{m}$. Microhardness measurement HV 0.1 (Fig. 2) showed a deformation strengthening in the surface layers induced by shot peening and the hardness increased from average value $240 \mathrm{HV} 0.1$ of the core of the specimen to about 300 HV0.1 slightly under the treated surface.

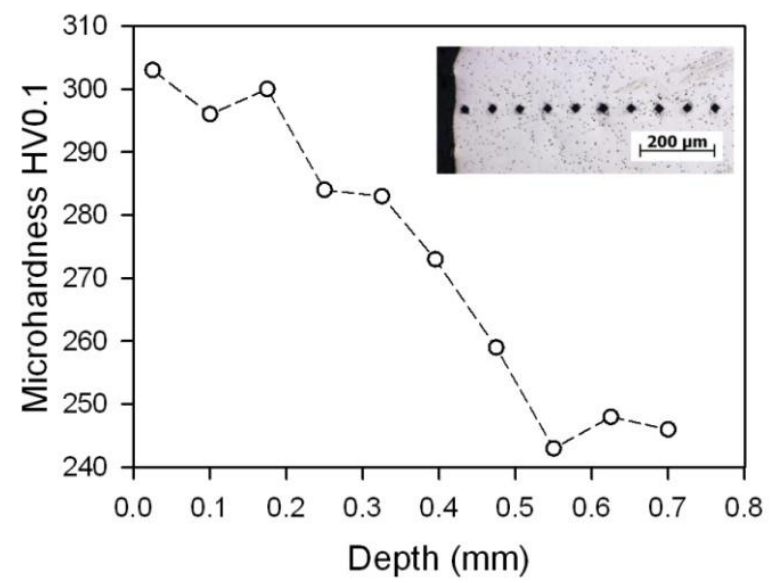

Fig. 2. The dependence of hardness on the distance from shot peened surface of the specimen.

Source: own study.

\subsection{Tensile properties}

For tensile tests three ground were used and three shot peened specimens. The results of tensile tests (Tab. 2) showed a $124 \%$ increase of yield strength, however no increase of tensile strength was observed. The elongation decreased by the shot peening treatment for $25 \%$.

Table 2. Results of tensile tests on specimens before and after shot peening

\begin{tabular}{|c|c|c|c|}
\hline & $\begin{array}{c}\text { Tensile } \\
\text { strength } \\
\mathrm{R}_{\mathrm{m}}(\mathrm{MPa})\end{array}$ & $\begin{array}{c}\text { Yield strength } \\
\mathrm{R}_{\mathrm{p} 0,2}(\mathrm{MPa})\end{array}$ & $\begin{array}{c}\text { Elongation } \\
\mathrm{A}(\%)\end{array}$ \\
\hline $\begin{array}{c}\text { Before shot } \\
\text { peening }\end{array}$ & 778 & 287 & 54 \\
\hline $\begin{array}{c}\text { After shot } \\
\text { peening }\end{array}$ & 752 & 643 & 40 \\
\hline
\end{tabular}

\subsection{Fatigue properties}

Rotating bending fatigue tests (frequency of loading $\mathrm{f}=50 \mathrm{~Hz}$, temperature $\mathrm{T}=20 \pm 3{ }^{\circ} \mathrm{C}$, ratio of cycle asymmetry $\mathrm{R}=-1$ ) were performed to evaluate the influence of shot peening on the fatigue strength of the experimental material.

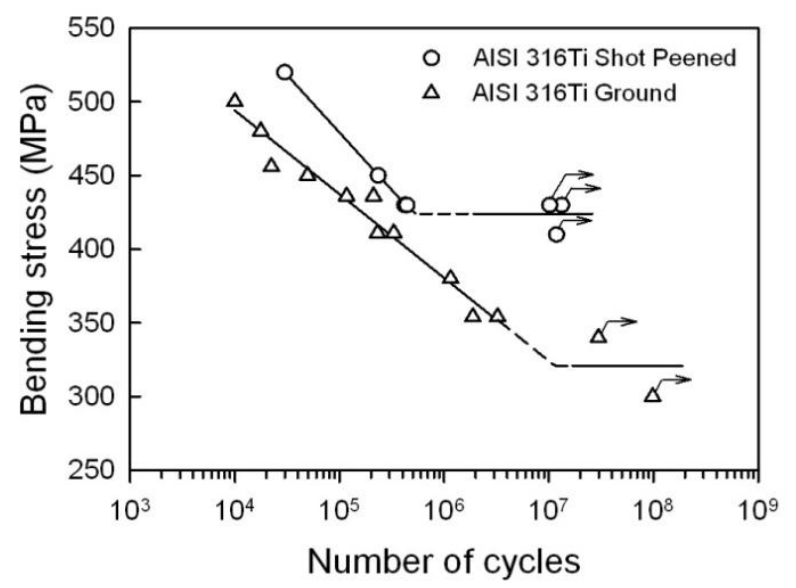

Fig. 3. The dependence of bending stress vs. number of cycles, steel AISI 316Ti.

12 ground specimens were tested and 7 shot peened specimens and the run - out number of cycles for fatigue limit $\sigma_{\mathrm{C}}$ determination was defined as $\mathrm{N}=10^{7}$ cycles. The dependence of bending stress $\sigma_{\mathrm{a}}$ vs. number of cycles to failure (or run - out) $\mathrm{N}$ is shown in Fig. 3 and the fatigue limit for machined specimens was determined as $\sigma_{\mathrm{C}}=320 \mathrm{MPa}$ and after shot peening as $\sigma_{\mathrm{C}}=420 \mathrm{MPa}$.

\subsection{Residual stress analysis}

The values of residual stress of shot peened specimens were measured by $\mathrm{X}$ - ray diffraction. To obtain dependence of residual stress on the distance from the shot peened surface (Fig. 4), small layers of material were systematically removed by electropolishing and each time the value of residual stress was measured.

With the use of X - ray diffractometer the FWHM (Full Width at Half Maximum) parameter was also measured which represents the dislocation density together with grain size and non-oriented micro-strain. The FWHM parameter, in this particular case, can be considered as the index of work hardening. Measurement of residual stress and FWHM was performed in three directions, which are determined by the $\varphi$ angle and when $\varphi=0^{\circ}$ the measurement results represent the axial residual stress, $\varphi=90^{\circ}$ the circumferential residual stress and the $\varphi=45^{\circ}$ is a measurement "in be- 
tween" to have information about the residual stresses in three directions.

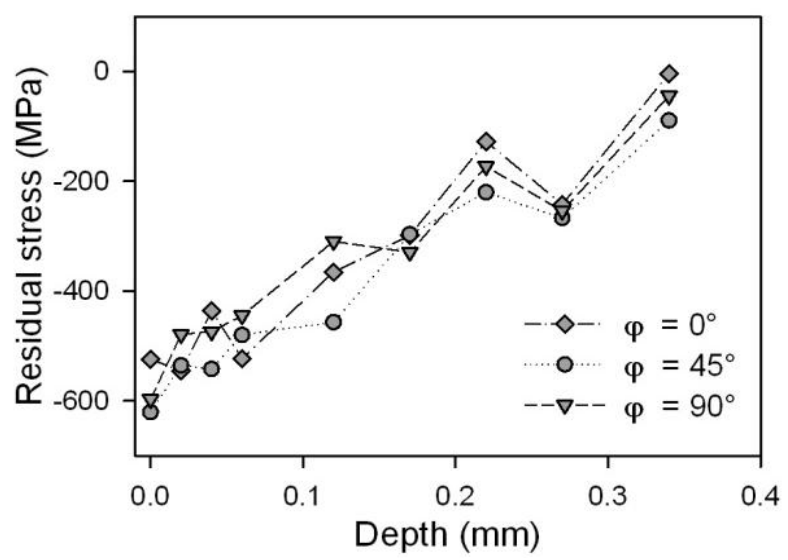

(a)

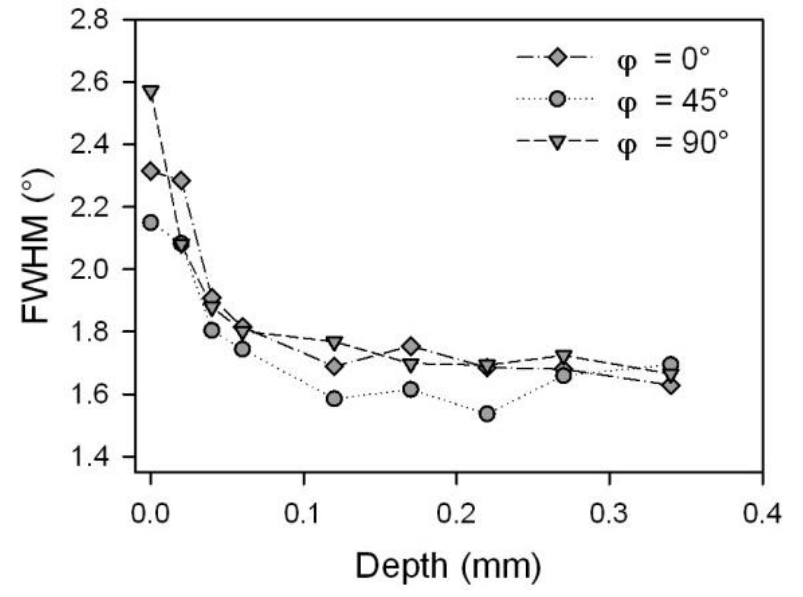

(b)

Fig. 4. The dependence of residual stress (a) and FWHM parameter (b) on the distance from the shot peened surface, steel AISI $316 T i$.

Shot peening treatment introduced three-axial compressive residual stresses in the subsurface layers of the material up-to depth of $0.3 \mathrm{~mm}$, however the depth of increased FWHM parameter is only about $0.1 \mathrm{~mm}$.

\section{Discussion}

Shot peening of $\mathrm{Cr}-\mathrm{Ni}-\mathrm{Mo}$ Austenitic stainless steel increased the hardness of surface layers almost to the depth of $0.5 \mathrm{~mm}$. The depth of hardness improvement is dependent on the shot peening parameters and on the shot peened specimen geometry (the ratio be- tween the specimen diameter and the diameter of peening media which defines the contact conditions). The surface strengthening due to the shot peening resulted in the yield stress improvement (from 287 to $643 \mathrm{MPa}$ ) however, the ultimate tensile strength remained almost the same as in the case of ground specimens. The elongation of the shot peened material was slightly lower when compared to the ground material. The fatigue limit for rotating - bending loading increased for $\Delta \sigma_{\mathrm{C}}=100 \mathrm{MPa}$, which represents an increase of 31 $\%$.

The obtained results: Fig. 2 (dependence of hardness on the distance from shot peened surface), Fig. $4 \mathrm{a}$ (dependence of residual stress on the distance from the shot peened surface), Fig. 4b (dependence of FWHM parameter on the distance from the shot peened surface) are in good correlation and decrease of compressive residual stresses and decrease of FWHM parameter corresponds with decrease of HV0.1 hardness with increasing distance from the shot peened surface of the specimen (GUAGLIANO M. 2010; TOSHA K. 2002).

The results of fatigue properties of AISI 316Ti steel after shot peening application proved higher resistance against fatigue loading in the area of $\mathrm{N}=2 \times$ $10^{4}$ cycles up to $\mathrm{N}=10^{7}$ cycles, Fig. 3 . Fatigue specimens surface is the mostly loaded area in the case of bending fatigue testing. The surface strength after shot peening was higher when compared to the ground material. However, by the surface strengthening due to the shot peening treatment the fatigue crack initiation became more difficult and the fatigue crack propagation rate in the early stages is lower. Part of the observed improvement in fatigue performance after shot peening could also be attributed to local strain-induced Martensitic transformation in the near-surface regions (Wollmann M., Mhaede M., Wagner L. 2011). The decreasing line of the $\mathrm{S}-\mathrm{N}$ diagram is shifted to higher values of cycles and the fatigue limit $\sigma_{\mathrm{C}}$ of experimental material before shot peening (evaluated for a run-out at $\mathrm{N}=10^{7}$ cycles) was $\sigma_{\mathrm{C}}=320 \mathrm{MPa}$ and after shot peening application the fatigue limit increases to value of $\sigma_{\mathrm{C}}=420 \mathrm{MPa}$; so the increase of fatigue limit is almost $31 \%$. These conclusions correspond with previous research (WOLlMANN M., MHAEDE M., WAGNER L. 2011; GuAGLIANO M. 2010; TOSHA K. 2002; ABADIE F. et al. 2006; ChAMPAGNe J. 2001; MÜLLER E. 2010). 


\section{Conclusions}

According to analysis of the influence of shot peening surface strengthening on AISI 316Ti stainless steel, it can be concluded that:

- the surface hardness was improved $24 \%$ by shot peening treatment (from $240 \mathrm{HVO} 0.1$ at a depth of 0.5 $\mathrm{mm}$ under the surface to $300 \mathrm{HVO} 0.1$ at a depth of 0.025 $\mathrm{mm})$,

- yield strength increased by $124 \%$ (from 287 to $643 \mathrm{MPa}$ ) however, the elongation decreased for $25 \%$ (from $54 \%$ to $40 \%$ ),

- $31 \%$ increase of fatigue limit after shot peening was observed (fatigue limit for machined specimens was determined as $\sigma_{\mathrm{C}}=320 \mathrm{MPa}$ and after shot peening as $\sigma_{\mathrm{C}}=420 \mathrm{MPa}$ ).

- shot peening treatment introduced bi-axial compressive residual stress field in the subsurface layers of material with maximal value of $\sigma_{\mathrm{R}} \approx-600 \mathrm{MPa}$ on the shot peened surface.

\section{Additional information}

The research is supported by European regional development fund and Slovak state budget by the project ITMS 26220220121 (95\%). The authors are grateful for the support of experimental works by project APVV SK-RO-0008-12 (5\%).

\section{Literature}

1. Abadie F. et al. 2006: Shot Peening: A Dynamic Application and its Future, 2nd Edition. MFN, Zurich.

2. Champagne J. 2001: Shot Peening Overview. In The Shot Peener. [online]. Available on the internet: http://www.shotpeener.com/library/spc/2001012.htm

3. FAJNOR P., LIPTÁKOVÁ T., ZATKALÍKOVÁ V., BREZINOVÁ J. 2011: Pitting corrosion of AISI 316Ti stainless steel with various treated surface, Perner's Contacts, Special Issue 2, Volume VI.

4. Guagliano M. 2010: Mechanical Surface Treatment for Improving the Fatigue Behavior of Metal Alloys, In: Letná škola únavy 2010 (Summer School of Fatigue 2010), EDIS, Žilina.

5. HADZIMA, B.; LIPTÁKOVÁ, T. 2008: Basics of Electrochemical corrosion of metals, EDIS, Žilina. (in Slovak)

6. LIPTÁKOVÁ, T. 2009: Pitting corrosion of stainless steels. EDIS, Žilina. (in Slovak)
7. LUONG H., HiLl M.R. 2010: The effects of laser peening and shot peening on high cycle fatigue in 7050-T7451 aluminum alloy, Mater. Sci. \& Engng., Vol. 527. No. 3.

8. Miková K., Guagliano M., BoKU゚VKa O., TrŠKo L., NoVÝ F. 2012: The role of shot peening in increasing X70 steel fatigue properties, Communications Scientific Letters of the University of Zilina, Vol. 14, No. 4.

9. MÜller E. 2010: Metal Finishing News 11. Available on the internet: http://www.mfn.li/article/?id=932

10. MurTy Y. V. 2004: Use of Stainless Steels in Medical Applications, Medical Device Materials: Proceeding of the Materials and Processes for Medical Devices Conference, ASM International, California.

11. Pariente I.F., Guagliano M. 2009, Contact fatigue damage analysis of shot peened gears by means of X-ray measurements, Engineering Failure Analysis, Vol. 16, No. 33.

12. SZKLARSKA - SMIALOWSKA, Z. 2005: Pitting and crevice corrosion, NACE International, Houston, Texas.

13. TOSHA K. 2002: Influence of Residual Stresses on the Hardness Number in the Affected Layer Produced by Shot Peening, In: 2nd Asia-Pacific Forum on Precision Surface Finishing and Deburring Technik, Seoul 2002, pp. 48-54.

14. Wollmann M., Mhaede M., Wagner L. 2011: Effect of Austenite Stability on Phase Transformation and Fatigue Performance of Stainless Steels after Various Mechanical Surface Treatments, http://www.shotpeener.com/library/pdf/2011047.pdf

15. YU-KUI G. 2004: Microstructure changes and residual stresses of each phase caused by shot peening in 304 austenitic stainless steel, Chineese Journal of Nonferrous Metals, Vol. 1, No. 1.

16. ZATKALÍKOVÁ V., BUKOVINA M., ŠKKORÍK V., PETREKOVÁ L. 2010: Pitting corrosion of AISI 316Ti stainless steel with polished surface, Materials Engineering - Materiálové Inžiniesrtvo, Vol. 17, No. 2.

17. ZHANG P., LINDEMANN J., LEYENS L. 2010: Shot peening on the high-strength magnesium alloy AZ80 - effect of peening media, J. of Mater. Proc. Technol., Vol. 210, No.3. 